\title{
Expression of a Calmodulin-dependent Phosphodiesterase Isoform (PDE 1B1) Correlates with Brain Regions Having Extensive Dopaminergic Innervation
}

\author{
Joseph W. Polli and Randall L. Kincaid \\ Section on Immunology, Laboratory of Molecular and Cellular Neurobiology, National Institute on Alcohol Abuse and \\ Alcoholism, Rockville, Maryland 20852
}

Cyclic nucleotide-dependent protein phosphorylation plays a central role in neuronal signal transduction. Neurotransmitter-elicited increases in CAMP/cGMP brought about by activation of adenylyl and guanylyl cyclases are downregulated by multiple phosphodiesterase (PDE) enzymes. In brain, the calmodulin (CaM)-dependent isozymes are the major degradative activities and represent a unique point of intersection between the cyclic nucleotide- and calcium $\left(\mathrm{Ca}^{2+}\right)$-mediated second messenger systems. Here we describe the distribution of the PDE1B1 (63 kDa) CaM-dependent PDE in mouse brain. An anti-peptide antiserum to this isoform immunoprecipitated $\approx 30-40 \%$ of cytosolic PDE activity, whereas antiserum to PDE1A2 (61 kDa isoform) removed $60-70 \%$, demonstrating that these isoforms are the major CaM-dependent PDEs in brain. Quantification of PDE1B1 immunoreactivity on immunoblots indicated that striatum contains 3-17-fold higher levels of PDE1B1 than other brain regions, with lowest immunoreactivity in cerebellum. In situ hybridization demonstrated high levels of PDE1B1 mRNA in the caudate-putamen, nucleus accumbens, and olfactory tubercle. Moderate mRNA levels were observed in dentate gyrus, cerebral cortex, medial thalamic nuclei, and brainstem, whereas negligible mRNA was detectable in the globus pallidus, islands of Calleja, substantia nigra, and ventral tegmental area. Immunocytochemistry confirmed that the majority of PDE1B1 protein was localized to the caudate-putamen, nucleus accumbens, and olfactory tubercle. Within the caudate-putamen, PDE1B1 immunoreactivity was ubiquitous, while PDE1A2 immunostaining was restricted to a minor subset of striatal neurons. The expression of PDE1B1 protein and mRNA correlate strongly with areas of the brain that are richest in dopaminergic innervation; indeed, there are strikingly similar distributions for PDE $1 B 1$ and $D_{1}$ dopamine receptor mRNAs. Since $D_{1}$ receptor binding activates adenylyl cyclase, and striatal neurons lack CaM-sensitive forms of cyclase, the high amount of this

\footnotetext{
Received Apr. 9, 1993; revised July 13, 1993; accepted Aug. 10, 1993.

We thank Dr. Polavarapu Rathna Giri for his advice and expertise, and Cheryl Marietta for help in antibody characterization. We are grateful to Drs. William Sonnenburg and Joseph Beavo for providing portions of the PDE1A2 cDNA clone. J.W.P. was supported in part by a Pharmacology Research Associate Trainee (PRAT) fellowship from the National Institutes on General Medical Sciences.

Correspondence should be sent to Joseph W. Polli, Department of Molecular Sciences, V-295, Glaxo Research Institute, 5 Moore Drive, Research Triangle Park, NC 27709; or Randall L. Kincaid, Department of Developmental Biology and Signal Transduction, Human Genome Sciences, 9620 Medical Center Drive, Rockville, MD 20850.

Copyright (C) 1994 Society for Neuroscience 0270-6474/94/141251-11\$05.00/0
}

PDE implies an important physiological role for $\mathrm{Ca}^{2+-r e g u-~}$ lated attenuation of cAMP-dependent signaling pathways following dopaminergic stimulation.

[Key words: cAMP, cyclase, striatum, dopamine, basal ganglia, DARPP-32]

Cyclic nucleotides, acting as "second messengers" or via direct cffccts, regulate a divcrsc array of ncuronal functions, from ion channel conductance to gene expression. Hydrolysis of $3^{\prime}, 5^{\prime}$ cyclic nucleotides to $5^{\prime}$-nucleoside monophosphates is the major mechanism for decreasing intracellular cyclic nucleotide levels. This reaction is catalyzed by cyclic nucleotide phosphodiesterase (PDE) enzymes that constitute a large superfamily (Beavo and Reifsynder, 1990). One family of PDE isozymes, which is highly enriched in brain compared to other tissues, is regulated by calcium $\left(\mathrm{Ca}^{2+}\right)$ through the $\mathrm{Ca}^{2+}$-binding protein calmodulin $(\mathrm{CaM})$. This apparent emphasis on $\mathrm{Ca}^{2+}$ modulation of cyclic nucleotide degradation suggests a close coupling of second messenger pathways in neural tissue. Although the CaM-dependent PDEs comprise only a small percentage $(0.03 \%)$ of total cellular protein in mammalian brain (Kincaid, 1987a), they are very efficient catalysts, exhibiting maximal turnover rates of $150-$ $300 \mathrm{sec}^{-1}$. Based on in vitro studies, CaM-PDEs are by far the predominant physiological regulators of cyclic nucleotide catabolism in brain, accounting for $>90 \%$ of PDE hydrolytic activity at micromolar cyclic nucleotide concentrations (Kincaid et al., 1981).

Biochemical and immunological studies have identified two major neuronal CaM-PDE isoforms that exhibit apparent subunit sizes of 63 and $61 \mathrm{kDa}$ (Sharma et al., 1984). The significance of such multiple $\mathrm{Ca}^{2+} / \mathrm{CaM}$-regulated PDE isoforms in brain is not clear and it is not known if these isozymes are colocalized in neurons or how their expression and activity are regulated in vivo. Previous studies using an affinity-purified polyclonal antibody demonstrated that CaM-PDE is highly enriched in specific neuronal populations such as neocortical and hippocampal pyramidal cells, and cerebellar Purkinje cells (Kincaid et al., 1987b); immunoreactivity was present in the somatic cytoplasm and throughout the extensive dendritic arborizations of these major output neurons. Electron microscopic studies further demonstrated that CaM-PDE immunoreactivity was highly localized in the postsynaptic region of asymmetric synapses (Ludvig et al., 1991), suggesting that CaM-PDEs subserve an important function in the dendrites of neurons that integrate multiple inputs.

Recently, cDNAs encoding the PDE1B1 (63 kDa) and PDE1A2 
(61 kDa) neuronal CaM-PDE isoforms were characterized (Bentley et al., 1992; Polli and Kincaid, 1992; Repaske et al., 1992; Sonnenburg et al., 1993). These isozymes are products of two separate but homologous genes (Novack et al., 1991) that appear to have diverged long ago. The most striking difference between these two isoforms lies in the expression of their mRNAs in the brain. The mRNA encoding the PDE1Bl isoform is expressed at 4-30-fold higher levels in the striatum than in other brain regions (Polli and Kincaid, 1992), whereas PDE 1 A2 mRNA appears to be more evenly distributed (Sonnenburg et al., 1993).

Although the immunocytochemical distribution of CaM-PDE in the adult and developing CNS has been carefully documented (Billingsley et al., 1990), the distribution and localization of individual CaM-PDE isoenzymes have not been determined. In order to gain insight into the biological roles and regulation of individual CaM-PDE isoforms, we have used immunological analyses and in situ hybridization (ISH) to characterize the expression of the PDEIBI isoform in the mouse CNS. These studies demonstrate that the majority of PDE1B1 mRNA and protein are expressed in brain regions that receive high amounts of dopaminergic innervation, suggesting that this CaM-PDE isoform plays an important role in the antagonism of cAMPregulated signaling in dopaminoceptive neurons.

\section{Materials and Methods}

Materials. Restriction enzymes and T4 DNA ligase were purchased from Promega. DNA sequencing was carried out using the Sequenase DNA Sequencing kit from U.S. Biochemical. Components for polymerase chain reaction (PCR) were obtained from Perkin-Elmer/Cetus and oligonucleotide primers were synthesized with a Cyclone Plus DNA synthesizer (MilliGen/Biosearch). Hybond nylon membranes for Southern blots were from Amersham and nitrocellulose membranes $(0.45 \mu \mathrm{m})$ for immunoblots were obtained from Schleicher and Schuell, Keene, NH. ${ }^{35}$ S-UTP was obtained from Amersham and ${ }^{35}$ S-dATP was purchased from New England Nuclear/DuPont. Electrophoresis reagents were obtained from Bio-Rad.

Baculovirus expression of PDE IBI. The open reading frame (-6 to 1605 base pairs) of mouse brain PDE1B1 (Polli and Kincaid, 1992) was amplified by PCR using primers containing BamHI restriction sites. The amplified DNA fragment was digested with BamHI, purified by polyacrylamide gel electrophoresis, and subcloned into BamHI-digested pVL1393 baculovirus expression vector. The PDE1B1/pVL1393 construct was transfected into Sf9 cells using a BaculoGold transfection kit (Pharmingen, San Diego, CA). Recombinant PDE1B1 virus was plaquepurified and high-titer viral stocks were prepared. For protein production, Sf9 cells were grown at $27^{\circ} \mathrm{C}$ in spinner flasks using Sf900II (GIB$\mathrm{CO} /$ Bethesda Research Labs) media containing $(50 \mu \mathrm{g} / \mathrm{ml})$ gentamicin. Cells $\left(1.5-2.0 \times 10^{6} / \mathrm{ml}\right)$ were infected at multiplicity of infection (MOI) $=5$ and incubated for $72 \mathrm{hr}$, and recombinant PDElBl protein was purified by calmodulin-Sepharose chromatography (Kincaid and Vaughan, 1988).

Animal housing and care. Male C57/BL6 mice (4-6 weeks of age) were used in all experiments and were obtained from the National Cancer Institute-Frederick Cancer Research Facility. Mice were housed in groups of three to five, kept on a $12 \mathrm{hr}: 12 \mathrm{hr}$ light/dark cycle, and fed ad libitum with Ziegler (NIH open Formula, Autoclavable) that was not autoclaved. Prior to any surgical procedures, animals were anesthetized with sodium pentobarbital $(50 \mathrm{mg} / \mathrm{kg})$ by intraperitoneal injection. All animal procedures were reviewed and approved by the Institutional Animal Care and Use Committee.

Preparation of antibodies against PDE1B1. The peptide Glu-Glu-AlaPro-Scr-Scr-Pro-Ala-Glu-Asp-Glu-His-Asn, representing amino acids 517-529 of mouse brain PDE1B1 (Polli and Kincaid, 1992), was synthesized by Cambridge Research Biochemicals (Wilmington, DE). An anti-peptide antibody was raised by immunization of rabbits with peptide conjugated to keyhole limpet hemocyanin through a cysteine added to the peptide amino terminus. Immunization and antibody purification procedures were essentially as described (Rathna Giri et al., 1992). Briefly, antisera were purified by affinity chromatography using peptide coupled to CH-Sepharose (substituent concentration of $0.5 \mathrm{mg}$ peptide/ $\mathrm{ml}$ of gel). Antibodies were eluted with $25 \mathrm{~mm}$ sodium acetate buffer, $\mathrm{pH} 4.8$, containing $6 \mathrm{~m}$ urea, $0.5 \mathrm{M} \mathrm{NaCl}, 2 \mathrm{~mm}$ EDTA, and $2 \mathrm{~mm}$ EGTA. Eluates were neutralized immediately with $2 \mathrm{~m}$ Tris- $\mathrm{HCl}, \mathrm{pH}$ 9.0 , and dialyzed against Tris-buffered saline (TBS; $50 \mathrm{~mm}$ Tris- $\mathrm{HCl}$, $\mathrm{pH} 7.4,150 \mathrm{~mm} \mathrm{NaCl}$ ) containing $40 \%$ glycerol. To purify the antibody further, a second round of affinity chromatography was completed using recombinant PDE1B1 protein that had been coupled to CNBr-Sepharose (substituent concentration of $1 \mathrm{mg} / \mathrm{ml}$ ). Antibody eluted from the peptide columns was pooled and $\mathrm{NaCl}$ added to a final concentration of $0.35 \mathrm{M}$. The pooled antibody $(\approx 10 \mathrm{mg}$ of $\mathrm{IgG}$ ) was rocked overnight with the PDE1B1 CNBr-Sepharose at $4^{\circ} \mathrm{C}$. The column (1 $\mathrm{ml}$ bed vol)

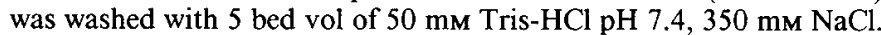
Antibody was eluted as described above and immediately dialyzed against TBS $/ 40 \%$ glycerol.

Isolation of brain tissues. Tissue was isolated from six discrete brain regions (cerebral cortex with olfactory tubercle, hippocampus, striatum, cerebellum, olfactory bulb, and hindbrain) and homogenized in 3 vol of ice-cold $10 \mathrm{~mm}$ Tris- $\mathrm{HCl}$, pH 7.2, $1 \mathrm{~mm}$ EDTA, 1 mm EGTA, 20 $\mu \mathrm{M}$ leupeptin, $15 \mu \mathrm{M}$ antipain, $0.5 \mu \mathrm{M}$ soybean trypsin inhibitor, $3 \mu \mathrm{M}$ pepstatin A, and $575 \mu \mathrm{M}$ phenylmethylsulfonyl fluoride. Homogenates were centrifuged at $100,000 \times g$ for $30 \mathrm{~min}$ and cytosolic fractions (S3) isolated. The protein content of fractions was determined by the method of Bradford (1976).

Polyacrylamide gel electrophoresis and immunoblotting analysis. SDSpolyacrylamide gel electrophoresis was carried out using $9 \%$ acrylamide gels. After electrophoresis, gels were either stained with Coomassie brilliant blue R-250 or used for electrophoretic transfer of proteins to nitrocellulose (Towbin et al., 1979). After blocking in a solution of $3 \%$ nonfat dry milk (Carnation) in dissolved TBS, blots were incubated with antibodies, washed and developed with bromochloroindolyl phosphate and nitro-blue tetrazolium as described (Polli et al., 1991).

In situ hybridization (ISH). The open reading frame ( 1605 base pairs) of mouse brain PDE1B1 (Polli and Kincaid, 1992) was amplified by PCR using oligonucleotide primers that contained either an EcoRI or BamHI restriction site on the 5 ' terminus. The amplified DNA fragment was digested, purified, and subcloned into the EcoRI/BaMHI sites of the $\mathrm{pGEM} 3 Z$ vector (Promega). In vitro transcription was completed in $40 \mathrm{~mm}$ Tris- $\mathrm{HCl} \mathrm{pH} 7.6,6 \mathrm{~mm} \mathrm{MgCl}_{2}, 2 \mathrm{~mm}$ dithiothreitol (DTT), 5 U of rRNasin, $400 \mu \mathrm{M}$ each of ATP, GTP, and CTP, $25 \mu \mathrm{M}{ }^{35}$ S-UTP $(800 \mathrm{Ci} / \mathrm{mmol}$; Amersham), $1 \mu \mathrm{g}$ of linearized plasmid (EcoRI for "antisense" riboprobe or BamHI for "sense" riboprobe), and 15 U of SP6 (antisense riboprobe) or T7 (sense riboprobe) RNA polymerase, and incubated at $37^{\circ} \mathrm{C}$ for $60 \mathrm{~min}$. After transcription, the DNA template was digested with RNase-free DNase (Promega) for $30 \mathrm{~min}$ at $37^{\circ} \mathrm{C}$ and transcripts subjected to alkaline cleavage as described (Wilson and Higgins, 1989). Following alkaline cleavage, transcripts were extracted with water-saturated phenol:chloroform (1:1), followed by an extraction with chloroform:isoamyl alcohol (49:1) and unincorporated nucleotides were removed using G-50 Sephadex spin columns (Boehringer Mannheim). All riboprobes had specific activities of $>10^{9} \mathrm{cpm} / \mu \mathrm{g}$.

For ISH, brains were fresh frozen and sections $(20 \mu \mathrm{m})$ were mounted on silanized slides (Oncor, Gaithersburg, MD) by gently warming the section to room temperalure. Prior to hybridization, sections were pretreated as described (Young et al., 1986). Briefly, sections were postfixed for $5 \mathrm{~min}$ in $4 \%$ paraformaldehyde dissolved in phosphate-buffered saline (PBS; pH 7.4) at room temperature, rinsed twice in PBS (5 min each), and acetylated in $0.1 \mathrm{M}$ triethanolamine $\mathrm{pH} 8.0,0.9 \% \mathrm{NaCl}$, $0.25 \%$ acetic anhydride for $10 \mathrm{~min}$. Following acetylation, sections were dehydrated through a series of graded alcohols $(70 \%, 80 \%, 95 \%$, and $100 \%$ ) and chloroform, and then dried at $37^{\circ} \mathrm{C}$. As a control, several slides were treated after the acetylation step with R Nase A $(50 \mu \mathrm{g} / \mathrm{ml}$ in $0.1 \mathrm{~mm}$ Tris pH 7.6, $0.2 \mathrm{M} \mathrm{NaCl}$, and $1 \mathrm{~mm}$ EDTA) for $30 \mathrm{~min}$ at $37^{\circ} \mathrm{C}$. After incubation in RNase A, these slides were incubated in $4 \%$ paraformaldehyde/PBS to inactivate the ribonuclease, rinsed twice in PBS, and dehydrated. The remaining steps of the method were similar to those described by Wilson and Higgins (1989). All slides were prehybridized for $2 \mathrm{hr}$ at $42^{\circ} \mathrm{C}$ in $50 \%$ formanide, $0.75 \mathrm{M} \mathrm{NaCl}, 20 \mathrm{~mm}$ PIPES pH 6.8, $10 \mathrm{~mm}$ EDTA, 10\% dextran sulfate, $5 \times$ Denhardt's solution, $50 \mathrm{~mm}$ DTT, $0.2 \% \mathrm{SDS}, 100 \mu \mathrm{g} / \mathrm{ml}$ yeast tRNA, and $100 \mu \mathrm{g} /$ $\mathrm{ml}$ herring sperm DNA. Prehybridization solution was removed and hybridization solution containing antisense or sense PDE 1 B1 riboprobe added $\left(2 \times 10^{6} \mathrm{cpm} / \mathrm{slide}\right.$ in $100 \mu \mathrm{l}$ of prehybridization solution). Slides were hybridized for $16 \mathrm{hr}$ at $42^{\circ} \mathrm{C}$. After hybridization, slides were washed as described (Wilson and Higgins, 1989) with the final wash 

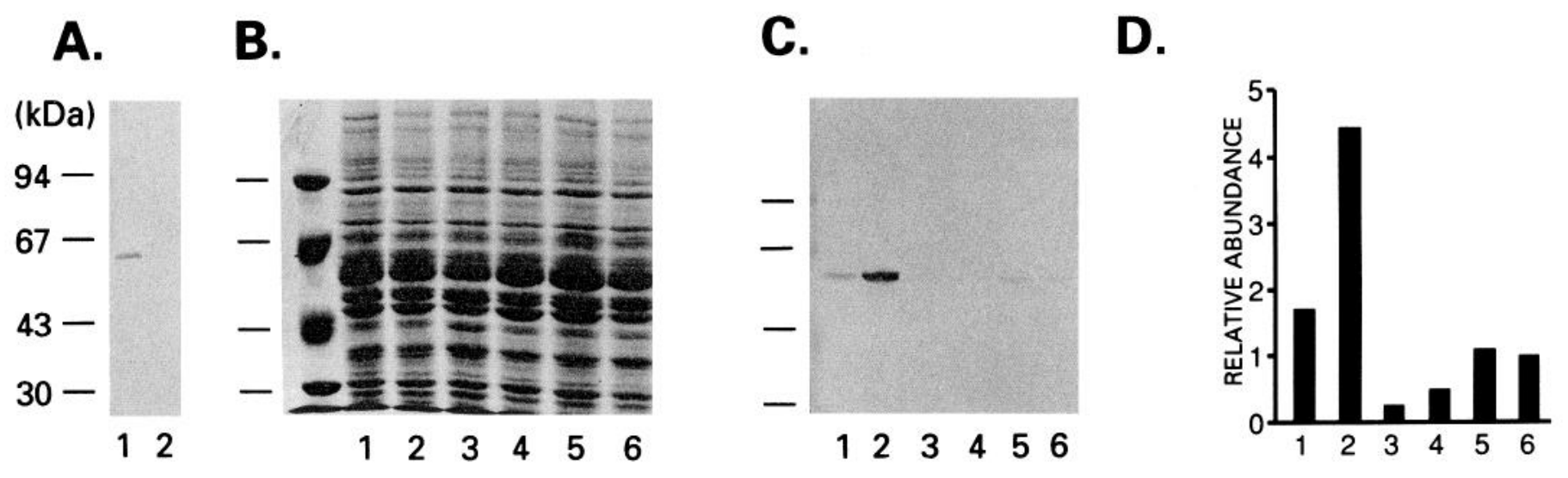

Figure 1. Regional distribution of PDE1B1 protein in mouse brain. An anti-peptide antibody was raised and affinity-purified as described in Preparation of antibodies against PDE1 B1 (Materials and Methods). The anti-peptide PDE1B1 antibody (400 ng/ml) recognizes purified recombinant PDE1B1 protein $(20 \mathrm{ng} /$ lane) produced in baculovirus-infected Sf9 cells $(A$, lane 1$)$ but does not cross-react with PDE1A2 protein ( $50 \mathrm{ng} /$ lane) purified from bovine cortex $(A$, lane 2). B-D, Cytosolic fractions $(100,000 \times g)$ from cortex (lane I), striatum (lane 2), cerebellum (lane 3), hippocampus (lane 4), olfactory bulb (lane 5), and hindbrain (lane 6) were resolved on 9\% SDS-polyacrylamide gels. Gels were stained with Coomassie brilliant blue R-250 $(B)$ or used for electrophoretic transfer of proteins to nitrocellulose for immunoblots. The anti-peptide antibody detects a single $\approx 63 \mathrm{kDa}$ immunoreactive band in all six regions $(C)$. Densitometric quantification of immunoreactive bands indicates that striatum contains 3-17-fold more PDE1B1 than other brain regions $(D)$.

being $0.2 \times \mathrm{SSC}\left(30 \mathrm{~mm} \mathrm{NaCl}, 3.0 \mathrm{~mm} \mathrm{Na}_{3}\right.$ citrate, $\left.\mathrm{pH} 7.0\right)$ at $55^{\circ} \mathrm{C}$. Slides were then rinsed briefly in distilled water and air dried for autoradiography using Hyperfilm- $\beta$ max (Amersham). After autoradiography, slides were coated with NTB2 emulsion (Kodak; diluted 1:1 with water) and developed as described by the manufacturer.

Immunocytochemistry. Animals were anesthetized as described above (see Animal housing and care) and perfused transcardially with PBS, followed by freshly prepared $4 \%$ paraformaldehyde dissolved in PBS $\mathrm{pH}$ 7.4. Brains were postfixed overnight at $4^{\circ} \mathrm{C}$ and sectioned $(50-75$ $\mu \mathrm{m})$ in ice-cold PBS using an Oxford Vibratome. Sections remained free-floating for the immunocytochemical reaction. Immediately after

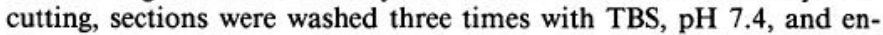
dogenous peroxidase activity was inactivated by incubation in $1 \mathrm{mg} /$ $\mathrm{ml}$ sodium azide/TBS containing $2 \% \mathrm{H}_{2} \mathrm{O}_{2}$. After $5 \mathrm{~min}$, sections were rinsed with TBS (three washes, 10 min each) and incubated with $2 \%$ normal goat serum $/ 0.3 \%$ Triton X-100 in TBS to reduce nonspecific binding. Primary antibody was added (1:250 in TBS/0.1\% Triton-X100/ $2 \%$ goat serum) for $18 \mathrm{hr}$ at $4^{\circ} \mathrm{C}$. Primary antibody was detected using a biotinylated secondary antibody (Vector Labs) and an avidin-horseradish peroxidase/diaminobenzidine/ $\mathrm{H}_{2} \mathrm{O}_{2}$ chromogen system. Sections were allowed to develop for $5 \mathrm{~min}$ and subsequently washed in TBS, mounted on gelatin-chrom alum-coated slides, and dehydrated through a series of graded alcohol/xylene steps.

Immunoprecipitation of CaM-PDE isoforms. A "PDE1A2"-specific polyclonal antiserum was prepared from a CaM-PDE antibody preparation (Kincaid, 1988) that contained a small amount of cross-reactivity to the PDE1B1 isoform (J. W. Polli and R. L. Kincaid, unpublished observations). The cross-reactive antibody population was removed by adsorption of the antiserum to recombinant PDE1B1 protein that had been immobilized on Immobilon-PF membranes. The resulting PDE1A2 antiserum did not immunoabsorb any CaM-dependent PDE activity in PC12 cells stably expressing the PDE1B1 isozyme (Polli and Kincaid, unpublished observations). Cytosolic tissue extracts were prepared as described above (see Isolation of brain tissues) and added to immunoprecipitation reactions $(500 \mu \mathrm{l}$; final protein concentration of $0.1-0.2$ $\mathrm{mg} / \mathrm{ml}$ diluted in PBS) containing either the PDE1B1 or PDE1A2 antiserum. After gently mixing the reactants at $4^{\circ} \mathrm{C}$ for $90 \mathrm{~min}, 40 \mu \mathrm{l}$ of Protein A-agarose (1:1 bed vol:vol in PBS; Pierce, Rockford, IL) was added and reactions incubated for a second $90 \mathrm{~min}$ period. The protein A-agarose:IgG complexes were removed from the cytosolic fraction by centrifugation at $3000 \times g$ for $10 \mathrm{~min}$ and CaM-dependent PDE activity assayed as described (Kincaid and Manganiello, 1988).

\section{Results}

Immunological analyses of PDE $1 B 1$ in brain

An anti-peptide antibody was raised against a region of deduced sequence located near the carboxyl terminus of the mouse brain
PDE1B1 (63 kDa) isoform (Polli and Kincaid, 1992) having no sequence homology to that of the PDE1A2 $(61 \mathrm{kDa})$ isoform (Sonnenburg et al., 1993). To demonstrate that the PDE1B1 anti-peptide antibody does not cross-react with the PDE1A2 isoform, blots containing purified recombinant PDE1B1 protein (generated in baculovirus-infected $\mathrm{Sf} 9$ insect cells) and a purified fraction of PDE1A2 from bovine cortex were incubated with affinity-purified PDE1B1 anti-peptide antibody (Fig. 1A). The

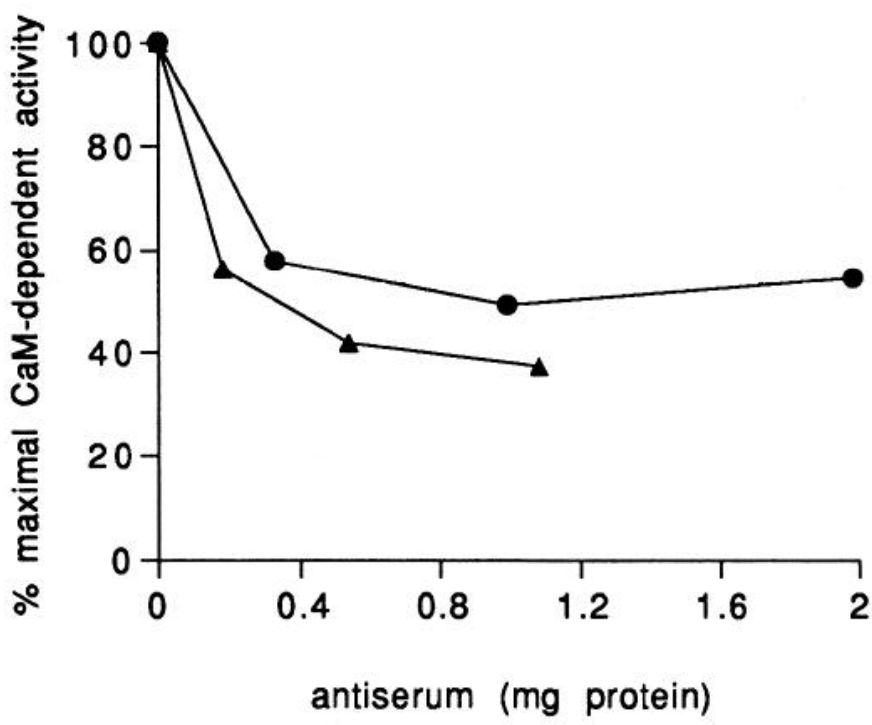

Figure 2. Immunoprecipitation of CaM-PDE isoforms from wholebrain cytosol. Specific antisera for the PDE1B1 and PDE1A2 isozymes were prepared and characterized as described in Immunoprecipitation of CaM-PDE isoforms (Materials and Methods). Whole mouse brain cytosol $(100,000 \times g$ fraction) was incubated for 90 min with varying amounts of antiserum and CaM-PDE:antibody complexes were precipitated with protein A-agarose beads. CaM-dependent PDE activity in cytosol was assayed as described (Kincaid and Manganiello, 1988). PDE1B1 antiserum $(\bullet)$ immunoprecipitated $\approx 30-40 \%$ of the CaMdependent PDE activity, whereas the PDE1A2 antiserum $(\boldsymbol{\Lambda})$ removed $60-70 \%$ of this activity. Control incubations using protein A-agarose alone or preimmune antiserum did not significantly alter CaM-PDE activity (data not shown). 
A

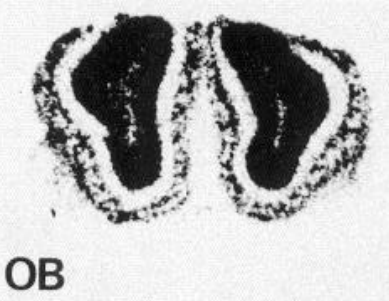

C

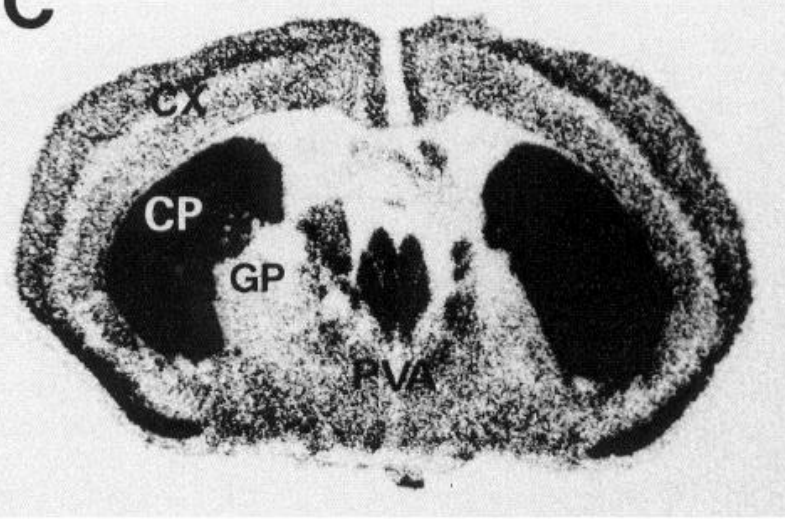

E

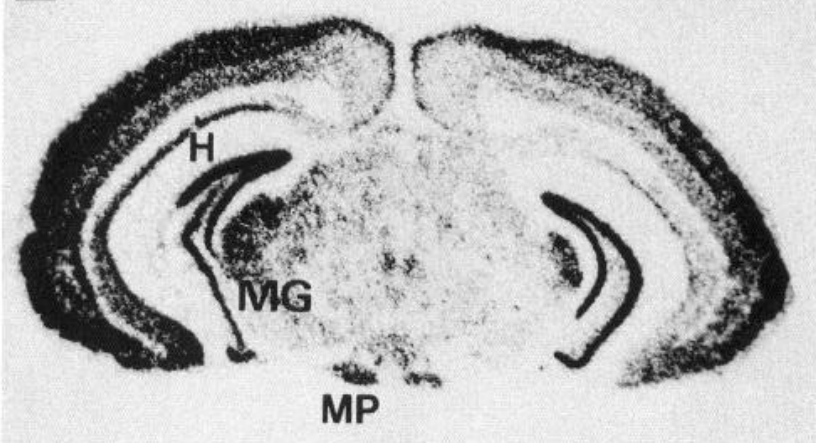

G
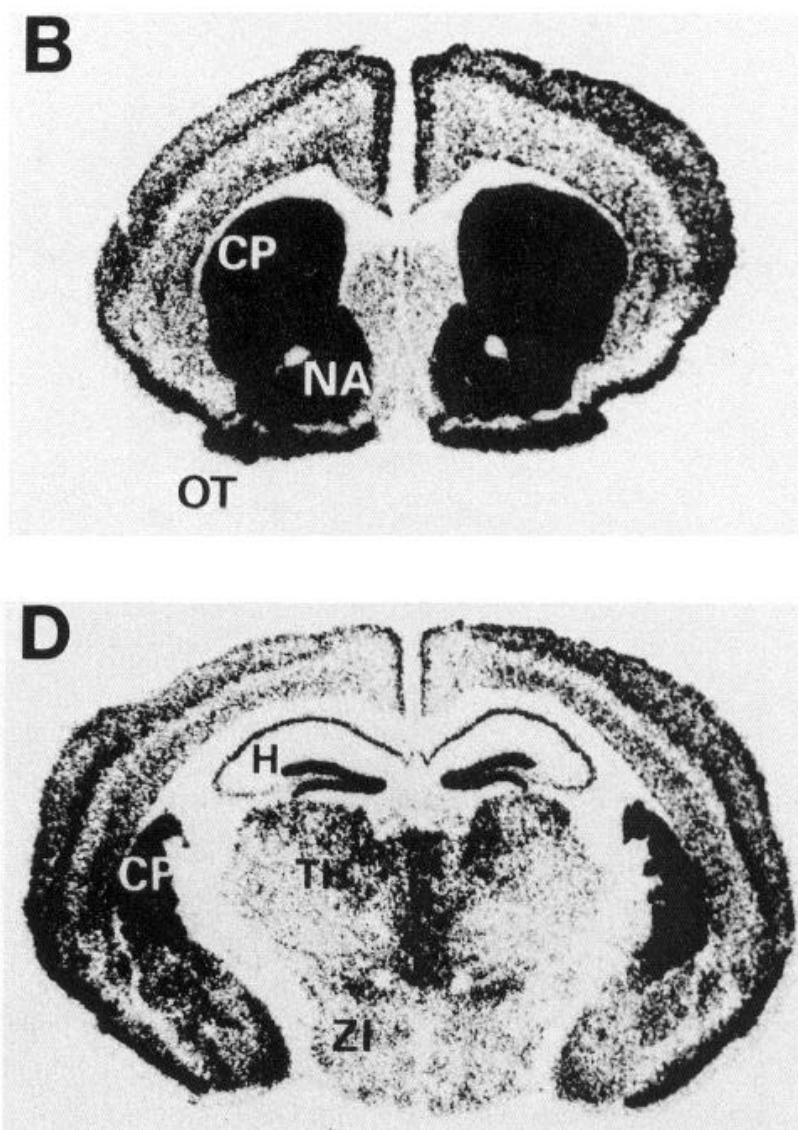

F

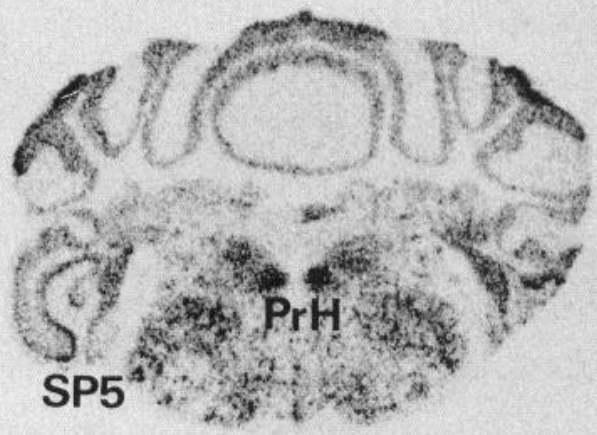

H
CP

NA

OT
CP

NA 

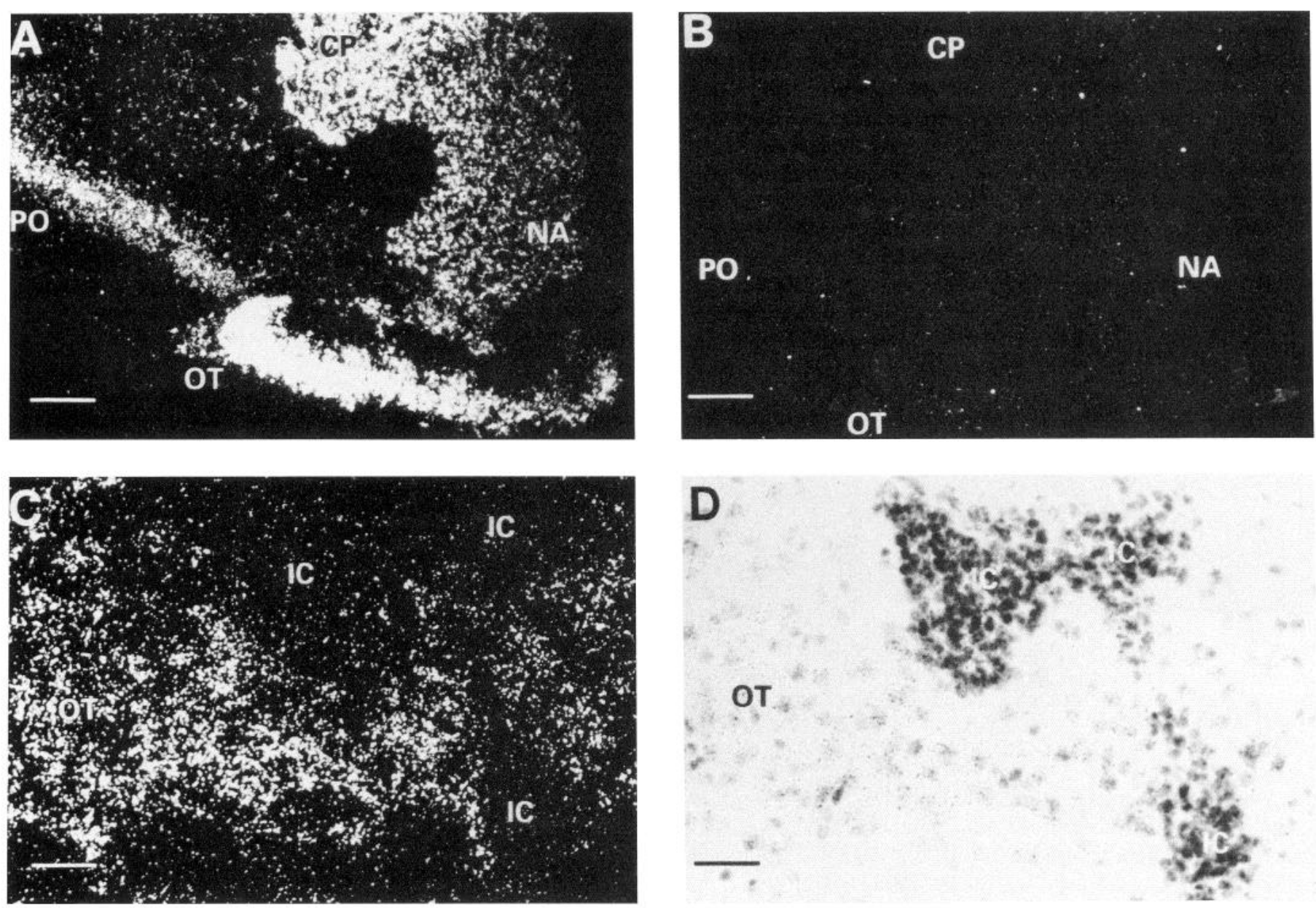

Figure 4. ISH of PDE1B1 mRNA in the striatum and olfactory tubercle. $A$ and $B$ are low-magnification $(40 \times)$ dark-field photomicrographs of emulsion-coated sections hybridized with a ${ }^{35}$ S-labeled antisense $(A)$ or sense $(B)$ PDE1B1 riboprobes. $C$ and $D$, Dark-field $(C)$ and bright-field $(D$; counterstained with cresyl violet acetate) microscopy at a higher magnification $(200 \times)$ shows that silver grains are localized to the pyramidal cell layer of the olfactory tubercle and not the islands of Calleja $(I C)$. PO, primary olfactory cortex; other abbreviations are as defined in Figure 3 . Scale bars: $A$ and $B, 250 \mu \mathrm{m} ; C$ and $D, 40 \mu \mathrm{m}$.

PDE1B1 antibody recognizes recombinant PDE1B1 (lane 1), but does not react with the PDE1A2 fraction (lane 2). The relative amounts of CaM-PDE isoforms in whole-brain cytosol were determined in immunoprecipitation experiments using antisera specific for the two isoforms. The PDE1B1 antiserum was capable of immunoprecipitating $\approx 30-40 \%$ of CaM-stimulated PDE activity from whole-brain cytosol, whereas the PDE1A2 antiserum removed $60-70 \%$ (Fig. 2; Polli and Kincaid, unpublished observations). PDE activity remaining in the cytosol after depletion by PDE1B1 antibody was removed by PDE1A2 immunoadsorption, indicating that these two isoforms account for essentially all CaM-dependent PDE activity. Control immunoprecipitations using protein A-agarose beads alone or incubation with preimmune rabbit antisera did not cause a significant loss of CaM-PDE activity (data not shown).

To evaluate the regional expression of PDE1B1 protein, a blot containing cytosolic fractions from six major brain areas was incubated with the PDE1B1 antibody (Fig. 1B). A single, $\approx 63 \mathrm{kDa}$ immunoreactive band was observed in all regions examined (Fig. 1C); however, the amount of immunoreactivity varied greatly between regions. Densitometric quantification of the immunoreactive bands indicated that striatum contains threeto fivefold higher PDE1B1 levels than cortex, olfactory bulb, and hindbrain, and 8-17-fold more than hippocampus and cerebellum (Fig. 1D).

\section{Localization of PDE IBI $\mathrm{mRNA}$ by ISH}

To compare the regional PDE1B1 protein distribution to the cellular localization of its mRNA, ISH studies were undertaken. The PDE1B1 probe used for these studies did not cross-hybridize to PDE1A2 mRNA based on Southern blots prepared using portions of the PDE1A2 (876 base pairs) and PDE1B1

Figure 3. Localization of PDE1B1 mRNA in mouse brain. Brain sections were hybridized with either a ${ }^{35}$-labeled antisense $(A-F, H)$ or sense $(G)$ riboprobe and washed, and slides were placed for autoradiography for $5 \mathrm{~d}$. Several slides were pretreated with RNase A and subsequently hybridized with the ${ }^{35}$ S-labeled antisense probe $(H)$. $C P$, caudate-putamen; $C X$, cortex; $G P$, globus pallidus; $H$, hippocampus; $M G$, medial geniculate body; $M P$, mammillary peduncles; $N A$, nucleus accumbens; $O B$, olfactory bulb; $O T$, olfactory tubercle; $P r H$, prepositus hypoglossal nucleus; $P V A$, paraventricular nucleus; $S P 5$, trigeminal nerve; $T H$, thalamus; $Z I$, zona incerta. 

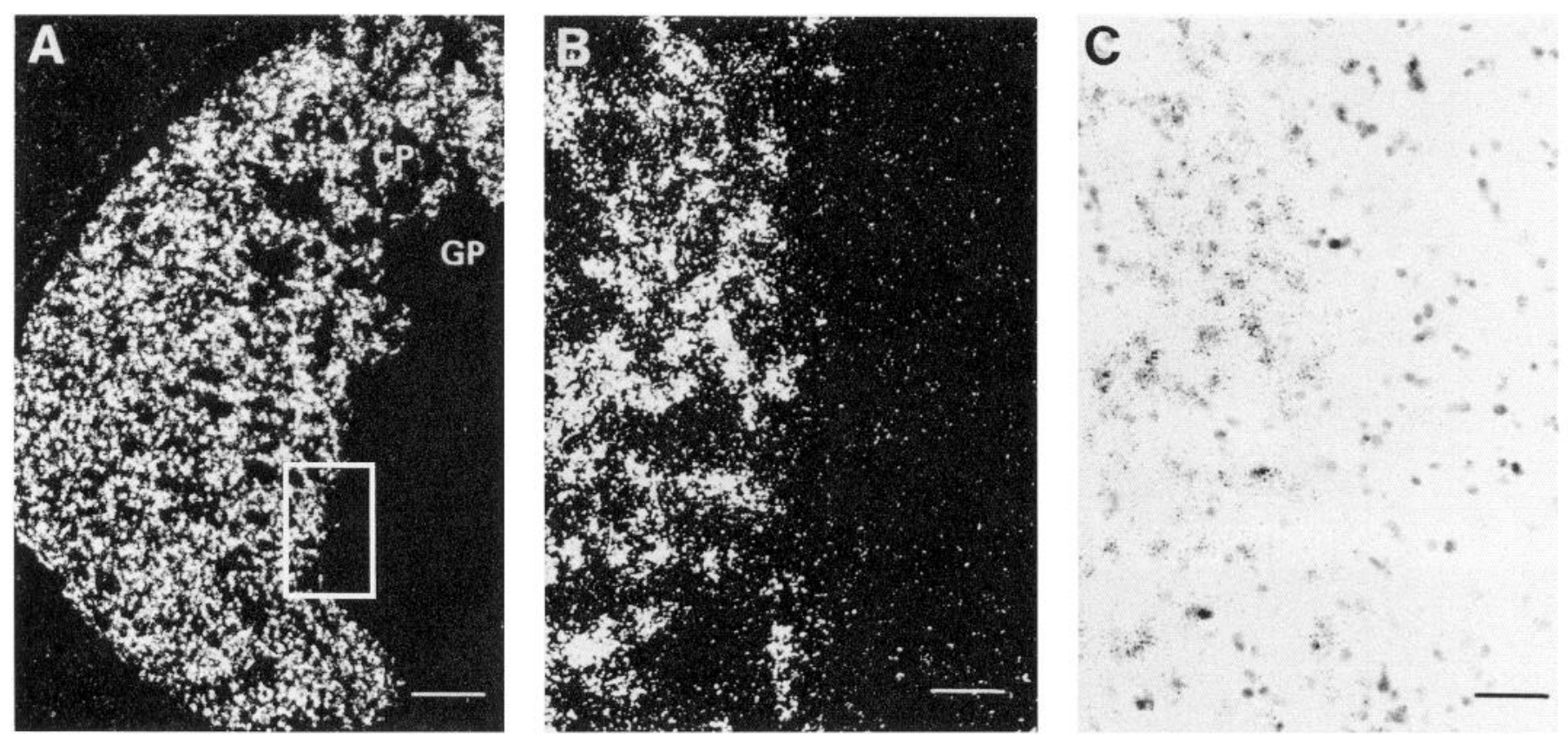

Figure 5. ISH of PDE1B1 mRNA in the caudate-putamen. $A$ is a low-magnification $(40 \times)$ dark-field photomicrograph of an emulsion-coated section of the caudate-putamen hybridized with a ${ }^{35} \mathrm{~S}$-labeled antisense PDE1B1 riboprobe. An abundance of silver grains are present in the caudateputamen. The globus pallidus is virtually free of any silver grains. $B$ and $C$, Dark-field $(B)$ and bright-field $(C$; counterstained with cresyl violet acetate) microscopy of the caudate-putamen/globus pallidus transition (boxed in $A$ ) at a higher magnification $(200 \times)$. Scale bars: $A, 40 \mu \mathrm{m} ; B$ and $C, 250 \mu \mathrm{m}$.

(1605 base pairs) open reading frames. Even under low-stringency hybridization conditions, the ${ }^{35} \mathrm{~S}-$ labeled PDE1B1 antisense riboprobe bound only to the PDE1B1 cDNA fragment, demonstrating that it is specific for the PDE1B1 isoform (data provided to reviewers).

Autoradiograms of brain sections incubated with an ${ }^{35} \mathrm{~S}$-labeled PDE1B1 antisense riboprobe showed intense hybridization signal in the caudate-putamen (CP), nucleus accumbens (NA), olfactory bulb (OB), olfactory tubercle (OT), and primary olfactory cortex (Fig. 3). Hybridization was also present in several medial thalamic nuclei $(\mathrm{TH})$ such as the paraventricular nucleus (PVA), reuniens nucleus, and rhomboid nucleus. Other regions expressing PDE1B1 mRNA included the zona incerta (ZI), mammillary peduncle (MP), medial geniculate body (MG), nucleus of Darkshevich (Fig. 3E), cerebral cortex, and hippocampus $(\mathrm{H})$. Within the hippocampus, the dentate gyrus contained higher levels of PDE1B1 transcript than the CA1-CA4 pyramidal cell layer (Fig. $3 D$ ), over which a slight gradient of PDE1B1 hybridization was seen. PDE1B1 transcript was observed throughout the cell layers of the cerebral cortex especially in layers III, V, and VI (Fig. $3 B$ ). A variety of brainstem nuclei such as the prepositus hypoglossal nucleus $(\mathrm{PrH})$, trigeminal nerve (SP5), nucleus tractus solitarius, and raphe nucleus contain moderate amounts of PDE1B1 mRNA (Fig. $3 F$ ). Very little hybridization was observed in the globus pallidus (GP), substantia nigra, hypothalamus, or ventral tegmental area (Fig. $3 C, E)$. Control hybridizations using either a ${ }^{35}$ S-labeled PDE1B1 sense riboprobe (Fig. $3 G$ ) or pretreatment of sections with RNase $\mathrm{A}$ followed by hybridization with the ${ }^{35} \mathrm{~S}$-labeled PDE1B1 antisense riboprobe (Fig. $3 H$ ) showed no significant signal.

The cellular localization of mRNA transcripts was determined by bright- and dark-field microscopy of emulsion-coated sections. Figure $4 A$ is a dark-field photomicrograph of the hybridization of the ${ }^{35} \mathrm{~S}$-labeled PDE1B1 antisense riboprobe to the caudate-putamen, nucleus accumbens, olfactory tubercle, and primary olfactory cortex. A gradient of PDE1B1 expression is seen from the caudate-putamen to the nucleus accumbens. In olfactory tubercle, PDE1B1 mRNAs are abundant, while the primary olfactory cortex shows significantly lower amounts. Control hybridizations using ${ }^{35} \mathrm{~S}$-labeled sense riboprobe (Fig. $4 B$ ) or pretreatment with RNAse A (data not shown) produced very few silver grains. At higher magnification, dark-field (Fig. $4 C$ ) and bright-field (Fig. 4D) microscopy of the olfactory tubercle shows that the silver grains are associated with the pyramidal layer of the olfactory tubercle and not with the islands of Calleja (IC).

The highest amount of PDE1B1 mRNA, by far, was found in the caudate-putamen of the basal ganglia (Fig. 5). Silver grains were evenly distributed throughout this region and were present in both the patch and matrix compartments of striatum. In contrast, the globus pallidus and ventral pallidum showed very little hybridization (Fig. 5A,B). Bright-field microscopy confirmed that silver grains in the caudate-putamen were localized over the cell bodies of most neurons (Fig. $5 C$ ). A moderate amount of PDE1B1 mRNA is present in the dentate gyrus (Fig. $6 A$ ) and a variety of brainstem nuclei (Figs. $3 F, 6 B$ ) such as the hypoglossal nucleus, nucleus tractus solitarius, trigeminal nerve, raphe nucleus, and vestibular nucleus. Fewer silver grains were found associated with the CA1-CA4 pyramidal neurons of the hippocampus (Fig. 6A) and the Purkinje neurons of the cerebellum (Fig. 6B).

\section{Immunocytochemical localization of PDE $1 B 1$ in mouse brain}

Immunocytochemical studies showed intense PDE1B1 immunoreactivity throughout the caudate-putamen, nucleus accumbens, and olfactory tubercle (Fig. $7 A$ ); these regions contain the vast majority of PDE1B1 in brain. Immunoreactive product was also present in the dentate gyrus, substantia nigra (SN), and 

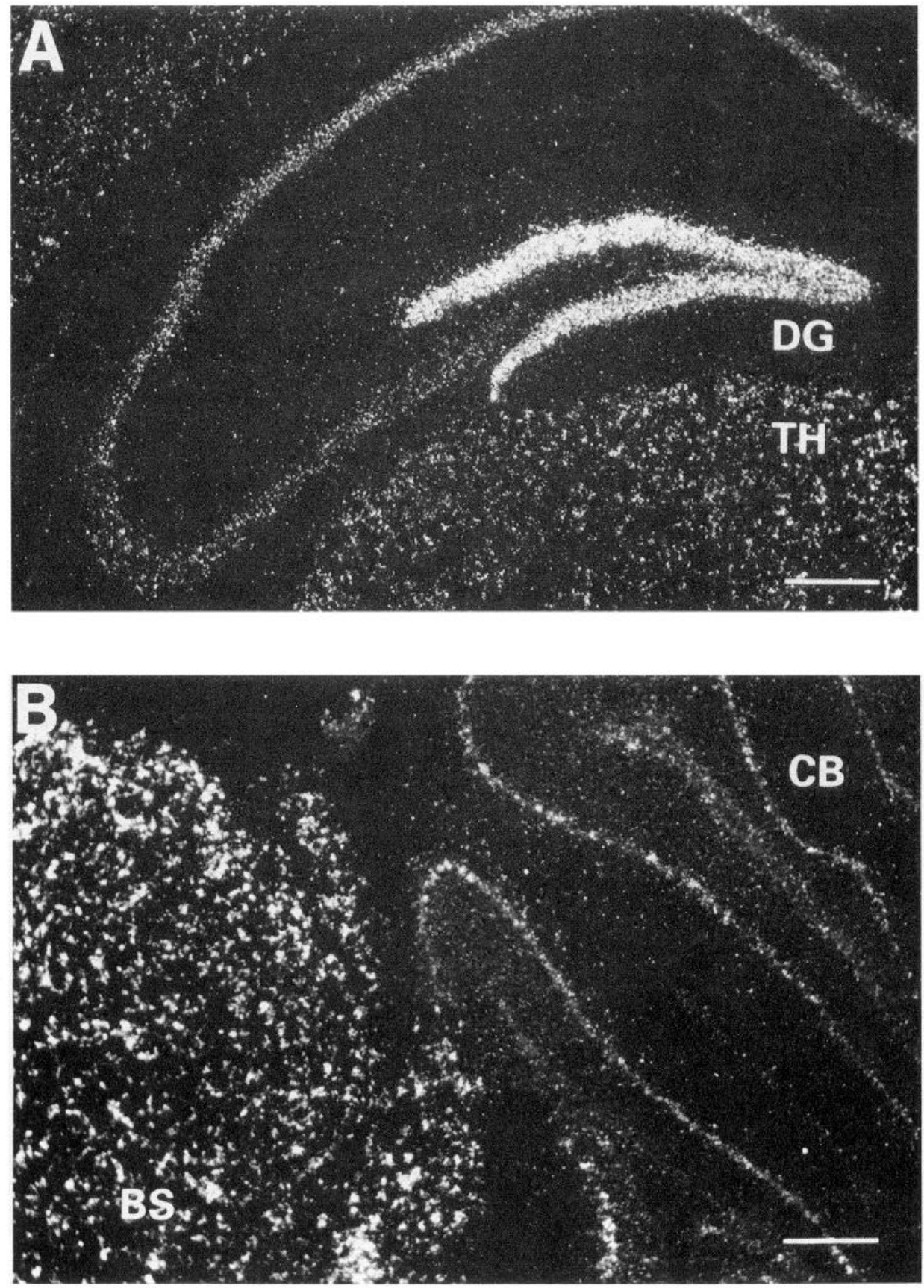

Figure 6. ISH of PDE1B1 mRNA in the hippocampus and brainstem. Lowmagnification $(40 \times)$ dark field of emulsion-coated sections hybridized with a ${ }^{35}$ S-labeled antisense PDE1B1 riboprobe shows that the majority of silver grains are found in the dentate gyrus $(D G)$ of the hippocampus $(A)$ and a variety of brainstem $(B S)$ nuclei $(B)$. Fewer silver grains are found over the CA1CA4 hippocampal pyramidal cells or cerebellar Purkinje cells. $T H$, thalamus; $C B$, cerebellum. Scale bars, $250 \mu \mathrm{m}$. cerebellar Purkinje cell layer. The neuropilar immunostaining in the substantia nigra, in conjunction with the absence of PDE1B1 mRNA in this region (Fig. 3E), suggests that the PDE1B1 protein is localized to the striatonigral pathway. Control experiments in which the antibody was preincubated with purified PDE1A2 protein had no effect on PDE1B1 immunostaining (Fig. $7 A$ ), while preincubation of antibody with recombinant PDE1B1 blocked all immunoreactivity (Fig. $7 B$ ). In the caudate-putamen, PDE1B1 immunoreactivity was ubiquitous (Fig. $8 \mathrm{~A}$ ) and was localized to the cell bodies of most medium spiny neurons. In contrast, PDE1A2 immunostaining was restricted to a minor subset of cells that comprise $<10 \%$ of striatal neurons (Fig. 8B). Based on the size of the cell body $(15-30 \mu \mathrm{m})$ and the number of stained neurons, the PDE1A2-containing neurons are not likely to be cholinergic interneurons. It is not clear if these cells also contain the PDE1B1 isoform.

\section{Discussion}

The immunocytochemical and biochemical data presented here establish that the $63 \mathrm{kDa}$ PDE1B1 CaM-regulated isozyme is a major neuronal form accounting for $\approx 30-40 \%$ of total CaMPDE activity in whole mouse brain. In terms of anatomical distribution, the expression of protein and mRNA for the $\mathrm{PDE} 1 \mathrm{~B} 1$ isoform in the adult is highly enriched in the caudateputamen, nucleus accumbens, and olfactory tubercle. These results agree with our initial report showing that striatum contains 4-30-fold more PDE1 B1 mRNA than other brain regions (Polli and Kincaid, 1992) and indicates that this biased transcript 


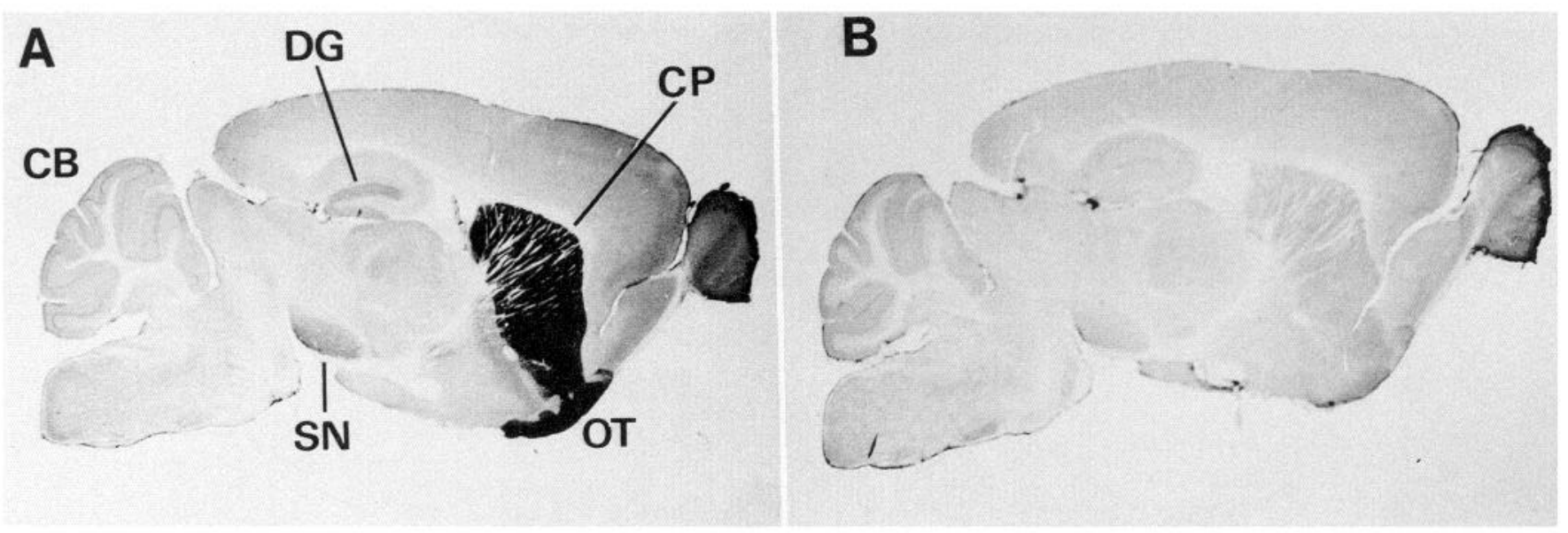

Figure 7. Immunocytochemical localization of PDE1B1 in mouse brain. Sections $(50 \mu \mathrm{m})$ were incubated with an affinity-purified PDE1B1 antibody that had been preabsorbed with purified PDE1A2 protein from bovine cortex $(1: 5$ molar ratio antibody:PDE1A2; $A)$ or recombinant PDE1B1 protein $(1: 5 ; B)$. The vast majority of PDE1B1 immunoreactivity is localized to the caudate-putamen $(C P)$, nucleus accumbens, and olfactory tubercle $(O T)$. Weaker immunostaining was also present in the substantia nigra $(S N)$, Purkinje cell layer of the cerebellum $(C B)$, and dentate gyrus $(D G)$. Control incubations using antibody preabsorbed with recombinant PDE1B1 exhibited no specific immunoreactivity $(B)$.

distribution is not due to differential rates of mRNA turnover. Perhaps equally important is the observation that the mRNA and protein of this isoform are in much lower amounts in cerebellum and the CA1-CA4 fields of the hippocampus, two areas with high immunoreactivity to a polyclonal antibody against purified CaM-PDE (Kincaid et al., 1987b). This suggests that the robust PDE immunoreactivity in these latter two areas represents primarily that of the PDE1A2 $(61 \mathrm{kDa})$ isoform, a conclusion supported by Western blot data showing that the polyclonal antibody preparation reacts only weakly to baculovirus-expressed PDE1B1 (Polli and Kincaid, unpublished observations). Similarly, molecular comparison of the distribution of PDE1B1 with the PDE1A2 CaM-PDE isoform reveals striking differences. PDE1A2 mRNA detected on Northern blots is evenly distributed in cerebral cortex, basal ganglia, hippocampus, and cerebellum (Sonnenburg et al., 1993). Consistent with these data, PDE1A2 immunoreactivity is present in these regions and the intensity of staining on immunoblots is similar among cortex, hippocampus, and striatum (Polli and Kincaid, unpublished observations). From immunoblots and immunoprecipitation experiments, we estimate that the PDE1B1 protein is higher than PDE1A2 (three to fivefold) in striatum and lower (fourto sixfold) in cerebellum. Although there appears to be significant disparity in the expression of these CaM-PDE isoenzymes within these two regions, large differences in the amounts of PDE1B1 and PDE1A2 immunoreactivity are not seen in other brain areas.

The most striking relationship seen in this study is the remarkable coincidence of our PDE1B1 ISH results with the expression of $\mathrm{D}_{1}$ dopamine receptor mRNA, which is also highest in caudate-putamen, nucleus accumbens, and olfactory tubercle (Weiner et al., 1991). Activation of $\mathrm{D}_{1}$ receptors stimulates adenylyl cyclase activity through the $\mathrm{G}$-protein $\mathrm{G}_{\mathrm{s}}$ (Creese et al., 1983), resulting in the synthesis of cAMP. This anatomical colocalization is consistent with a purposeful linkage of these signaling components. Although there is strong evidence suggesting that $D_{1}$ and $D_{2}$ receptors are colocalized in most striatal neurons (Surmeier et al., 1992), it seems unlikely that coexpression of $D_{2}$ receptor and PDE1B1 would be related necessarily since $D_{2}$ receptor activation inhibits adenylyl cyclase. The dopamine $\mathrm{D}_{3}$ receptor mRNA is enriched in the islands of Calleja of the olfactory tubercle (Sokoloff et al., 1990), a region devoid of PDE1B1 mRNA (Fig. $4 C, D$ ) and protein (Fig. $7 A$ ), suggesting that PDE1Bl does not play an important role in modulating the $\mathrm{D}_{3}$ signal. Indeed, we have recently obtained evidence suggesting that the major CaM-regulated PDE in the islands of Calleja is the PDE1A2 isoform (Polli and Kincaid, unpublished observations).

Even though the majority of PDE1B1 mRNA and protein is localized to regions that receive high amounts of dopaminergic innervation, PDE1B1 is expressed in other brain areas having less extensive dopaminergic innervation. For example, the mammillary body, medial geniculate body, zona incerta, paraventricular thalamic nucleus, and several brainstem nuclei express moderate levels of PDE1B1 mRNA. In these areas, a variety of other neurotransmitter receptors can modulate cyclic nucleotide levels. Muscarinic receptors $\mathrm{m} 2$ and $\mathrm{m} 4$ are negatively coupled to adenylyl cyclase, while activation of $\mathrm{m} 1, \mathrm{~m} 3$, and $\mathrm{m} 5$ receptors can, under specific conditions, increase cellular cAMP levels (Richards, 1991; Baumgold, 1992). Similarly, glutamate and NMDA have been demonstrated to increase cyclic nucleotide concentrations (Shimizu et al., 1974, 1975; Schmidt et al., 1976, 1977), as well as inhibiting adenylyl cyclase activity (Itano et al., 1992; Tanabe et al., 1992). Because of the diversity and complexity of neurotransmitter receptor families, it may be difficult to establish a clear anatomical or biological connection between these receptors and the expression of PDE1B1. Rather, it may be more appropriate to consider the need for $\mathrm{Ca}^{2+}$-dependent regulation of cyclic nucleotide levels in these regions.

The immunocytochemical staining of PDE1B1 within the striatum is similar to that seen for calcineurin (PP-2B), the CaMdependent protein phosphatase (Wallace et al., 1980; Wood et al., 1980; Goto and Hirano, 1989; Polli et al., 1991), suggesting that these CaM-binding proteins are colocalized in striatal neurons. Therefore, it seems plausible that one physiological function of PDE1B1 in striatum might be to participate along with calcineurin in a concerted $\mathrm{Ca}^{2+} / \mathrm{CaM}$-regulated antagonism of the cAMP second messenger system. Studies have shown that dopamine or cAMP analogs increase the phosphorylation of the 

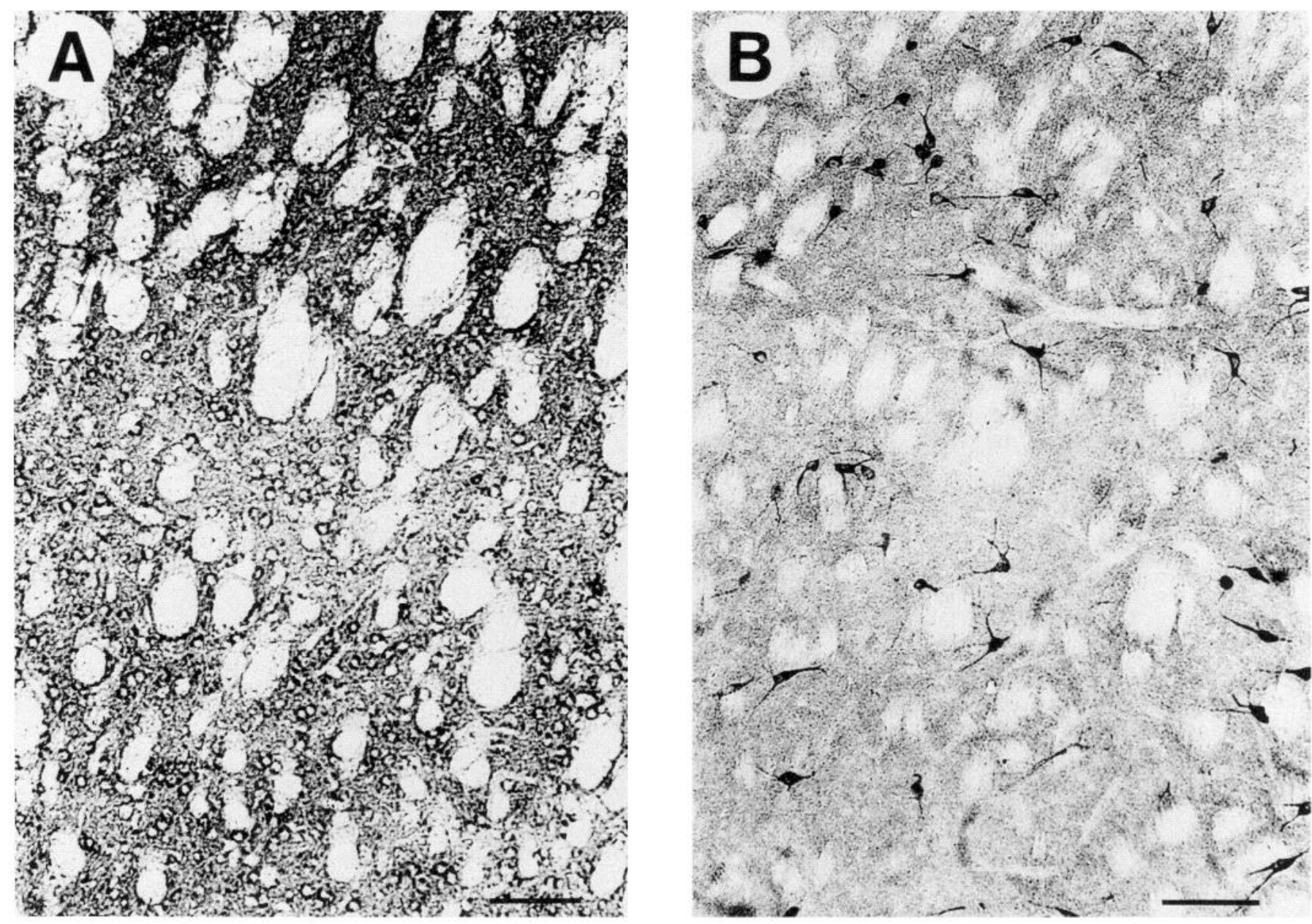

Figure 8. Immunocytochemical localization of PDE1B1 in caudate-putamen. Sections were stained with an affinity-purified PDE1B1 antibody that was preabsorbed with purified PDE1A2 protein from bovine cortex $(1: 5$ molar ratio antibody:PDE1A2; $A)$ and PDE1A2 antibody preincubated with recombinant PDE1B1 protein $(1: 5 ; B)$. Intense PDE1B1 immunoreactivity is found in the cell bodies of the majority of medium spiny neurons, whereas PDE1A2 immunoreactivity is restricted to a small subset of striatal neurons. Magnification, $100 \times$; scale bars, $100 \mu \mathrm{m}$.

phosphatase inhibitor DARPP-32 (dopamine- and cAMP-regulated phosphoprotein), resulting in the inhibition of the broad specificity protein phosphatase (PP)-1 (Hemmings et al., 1984; Shenolikar and Nairn, 1991). The phosphorylated form of DARPP-32 is a preferred substrate for calcineurin (King et al., 1984), and its dephosphorylation reverses the cAMP-induced suppression of PP-1. An increase in $\mathrm{Ca}^{2+}$ following receptor activation would activate both PDE1B1 and calcineurin, leading to the hydrolysis of cyclic nucleotides, the dephosphorylation of DARPP-32, and the activation of PP-1. Such a mechanism would serve to downregulate cAMP signaling cascades rapidly and may be particularly important as a means of preventing desensitization of dopaminergic response pathways, both at the cellular and at the systems levels.

Unique patterns of linkage between $\mathrm{Ca}^{2+}$ - and cyclic nucleotide-mediated signaling pathways are suggested by a careful examination of cyclic nucleotide biosynthetic components in brain. Notably, the distribution of the CaM-sensitive adenylyl cyclase in rat brain appears to be very different than that for PDE1B1 CaM-dependent PDE. Expression of mRNA for the CaM-sensitive adenylyl cyclase is highest in cerebellum and dentate gyrus (Xia et al., 1991), structures with low to moderate levels of PDE1B1 mRNA. Regions abundant in PDE1B1 mRNA, such as caudate-putamen, nucleus accumbens, and brainstem, have no detectable CaM-sensitive adenylyl cyclase signal. The mutually exclusive distribution of these CaM-sensitive signaling components in some structures may suggest that the $\mathrm{Ca}^{2+}$ signal in PDE1B1-containing neurons plays an obligatory role in counteracting cAMP generation, rather than augmenting cyclic nucleotide accumulation. On the other hand, the distribution of a soluble guanylyl cyclase in rat brain is similar to that of PDE1B1. Expression of this guanylyl cyclase mRNA is prominent in cortex, caudate-putamen, nucleus accumbens, and olfactory tubercle, while moderate levels of mRNA are found in the hippocampus, cerebellum, and brainstem (Matsuoka et al., 1992). The soluble guanylyl cyclase form is responsible for neurotransmitter-induced cGMP elevations in neurons. Recently a new CaM-insensitive adenylyl cyclase was shown to be selectively expressed in the striatum and was suggested to be responsible for the synaptic actions of dopamine (Glatt and Snyder, 1993). Since guanylyl cyclase and CaM-insensitive adenylyl cyclase activities are highest in striatum (Matsuoka et al., 1992), it maybe necessary to have large amounts of CaM-regulated PDE to achieve a vigorous reversal of cyclic nucleotide accumulation in response to elevated cellular $\mathrm{Ca}^{2+}$. Furthermore, unlike the PDE1A2 isoform, PDE1B1 activity is not subject to potential inhibition via phosphorylation by cAMP-dependent protein kinase (Sharma and Wang, 1985, 1986; Hashimoto et al., 1989), 
a modification that would delay the removal of cyclic nucleotides, resulting a prolonged cAMP response. This supports the idea that in striatal neurons PDE1B1 is essential to ensure an immediate $\mathrm{Ca}^{2+}$-regulated antagonism of the cAMP signal. By contrast, the apparent colocalization of PDE1A2 and CaM-sensitive adenylyl cyclases in some neurons (e.g., hippocampal pyramidal cells) may suggest a means to temporarily sustain cyclic nucleotide action in response to $\mathrm{Ca}^{2+}$, through increased synthesis and reduced degradative activity. Such an alternative strategy might be needed for proper temporal integration of excitatory input or to provide for long-term potentiation (Frey et al., 1993). Thus, despite their otherwise similar enzymological properties (i.e., $V_{\max }$, substrate affinities), the two major neural CaM-PDE isozymes may have operationally distinct roles. Future studies on the cellular localization of other CaM-PDE isozymes and the effect of phosphorylation in vivo on enzyme activity will be needed to establish the biological roles of the PDE1B1 and PDE1A2 CaM-dependent isoforms in neuronal signaling.

\section{References}

Baumgold J (1992) Muscarinic receptor-mediated stimulation of adenylyl cyclase. Trends Pharmacol Sci 13:339-340.

Beavo JA, Reifsynder DH (1990) Primary sequence of cyclic nucleotide phosphodiesterase isozymes and the design of selective inhibitors. Trends Pharmacol 11:150-155.

Bentley JK, Dadlecek A, Sherber C, Seger D, Sonnenburg WK, Charbonneau H, Novack JP, Beavo JA (1992) Molecular cloning of cDNA encoding a "63-kDa" calmodulin-stimulated phosphodiesterase from bovine brain. J Biol Chem 267:18676-18682.

Billingsley ML, Polli JW, Balaban CD, Kincaid RL (1990) Developmental expression of calmodulin-dependent cyclic nucleotide phosphodiesterase in rat brain. Dev Brain Res 53:253-263.

Bradford MM (1976) A rapid method for the quantification of microgram quantities of protein using the principle of dye binding. Anal Biochem 72:248-254.

Creese I, Sibley DR, Hamblin MW, Leff SE (1983) The classification of dopamine receptors: relationship to radioligand binding. Annu Rev Neurosci 6:43-71.

Frey U, Huang YY, Kandel ER (1993) Effects of cAMP stimulate a late stage LTP in hippocampal CA1 neurons. Science 260:1661-1664.

Glatt CE, Snyder SH (1993) Cloning and expression of an adenylyl cyclase localized to the corpus striatum. Nature 361:536-538.

Goto S, Hirano A (1989) Calcineurin in the postnatal striatum of the rat: an immunohistochemical study. Exp Brain Res 77:442-446.

Hashimoto Y, Sharma RK, Soderling TR (1989) Regulation of $\mathrm{Ca}^{2+}$ calmodulin-dependent cyclic nucleotide phosphodiesterase by the autophosphorylated form of $\mathrm{Ca}^{2+} /$ calmodulin-dependent protein kinase II. J Biol Chem 264:10884-10887.

Hemmings HC Jr, Greengard P, Tung HY, Cohen P (1984) DARPP32 , a dopamine-regulated neuronal phosphoprotein, is a potent inhibitor of protein phosphatase-1. Nature 310:503-505.

Itano Y, Murayama T, Kitamura Y, Nomura Y (1992) Glutamate inhibits adenylate cyclase activity in dispersed rat hippocampal cells directly via an $N$-methyl-D-aspartate-like metabotropic receptor. J Neurochem 59:822-828.

Kincaid RL (1988) Preparation, characterization and properties of affinity-purified antibodies to calmodulin-dependent cyclic nucleotide phosphodiesterase and the protein phosphatase calcineurin. Methods Enzymol 159:626-636.

Kincaid RL, Manganiello VC (1988) Assay of cyclic nucleotide phosphodiesterase using radiolabeled and fluorescent substrates. Methods Enzymol 159:457-470.

Kincaid RL, Vaughan M (1988) Purification and properties of calmodulin-activated cyclic nucleotide phosphodiesterase from mammalian brain. Methods Enzymul 159:557-573

Kincaid RL, Manganiello VC, Vaughan M (1981) Calmodulin activated cyclic nucleotide phosphodiesterase from brain. $\mathrm{J}$ Biol Chem 256:11345-11350.

Kincaid RL, Balaban CD, Billingsley ML (1987a) Regulated expres- sion of calmodulin-dependent cyclic nucleotide phosphodiesterase in the central nervous system. J Cyclic Nucleotide Protein Phos Res 11: $473-486$.

Kincaid RL, Balaban CD, Billingsley ML (1987b) Differential localization of calmodulin-dependent enzymes in rat brain: evidence for the selective expression of cyclic nucleotide phosphodiesterase in specific neurons. Proc Natl Acad Sci USA 84:1118-1122.

King MM, Huang CY, Chock PB (1984) Mammalian brain phosphoproteins as substrates for calcineurin. J Biol Chem 259:8080-8083.

Ludvig N, Burmeister V, Jobe PC, Kincaid RL (1991) Electron microscopic immunocytochemical evidence that the calmodulin-dependent cyclic nuclcotide phosphodicstcrase is localized predominantly at postsynaptic sites in the rat brain. Neuroscience 44:491-500.

Matsuoka I, Giuili G, Poyard M, Stengel D, Parma J, Guellaen G, Hanoune J (1992) Localization of adenylyl and guanylyl cyclase in rat brain by in situ hybridization: comparison with calmodulin mRNA distribution. J Neurosci 12:3350-3360.

Novack JP, Charbonneau H, Bentley JK, Walsh KA, Beavo JA (1991) Sequence comparison of the 63-, 61-, and 59-kDa calmodulin-dependent cyclic nucleotide phosphodiesterases. Biochemistry 30:79407947.

Polli JW, Kincaid RL (1992) Molecular cloning of DNA encoding a calmodulin-dependent phosphodiesterase enriched in striatum. Proc Natl Acad Sci USA 89:11079-11083.

Polli JW, Billingsley ML, Kincaid RL (1991) Expression of the calmodulin-dependent protein phosphatase, calcincurin, in rat brain: developmental patterns and the role of nigrostriatal innervation. Dev Brain Res 63:105-119.

Rathna Giri P, Marietta CA, Higuchi S, Kincaid RL (1992) Molecular and phylogenetic analysis of calmodulin-dependent protein phosphatase (calcineurin) catalytic subunit genes. DNA Cell Biol 11:415-424.

Repaske DR, Swinnen JV, Jin SLC, Van Wyk JJ, Conti M (1992) A polymerase chain reaction strategy to identify and clone cyclic nucleotide phosphodiesterase cDNAs. J Biol Chem 267:18683-18688.

Richards MH (1991) Pharmacology and second messenger interactions of cloned muscarinic receptors. Biochem Pharmacol 9:16451653.

Schmidt MJ, Ryan JJ, Molloy BB (1976) Effects of kainic acid, a cyclic analogue of glutamic acid, on cyclic nucleotide accumulation in slices of rat ccrcbellum. Brain Res 121:113-126.

Schmidt MJ, Thornberry JF, Molloy BB (1977) Effects of kainate and other glutamate analogues on cyclic nucleotide accumulation in slices of rat cerebellum. Brain Res 121:182-189.

Sharma RK, Wang JH (1985) Differential regulation of bovine brain calmodulin-dependent cyclic nucleotide phosphodiesterase isozymes by cyclic AMP-dependent protein kinase and calmodulin-dependent phosphatase. Proc Natl Acad Sci USA 82:2603-2607.

Sharma RK, Wang JH (1986) Calmodulin and $\mathrm{Ca}^{2+}$-dependent phosphorylation and dephosphorylation of 63-kDa subunit-containing bovine brain calmodulin-stimulated cyclic nucleotide phosphodiesterase isozyme. J Biol Chem 261:1322-1328.

Sharma RK, Adachi A, Adachi K, Wang JH (1984) Demonstration of bovine brain calmodulin-dependent cyclic nucleotide phosphodicsterase isozymes by monoclonal antibodics. J Biol Chem 259 . 9248-9254.

Shenolikar S, Nairn AC (1991) Protein phosphatases: recent progress. Adv Sec Messenger Phosphoprot Res 23:1-121.

Shimizu H, Ichishita H, Odagiri H (1974) Stimulated formation of cyclic adenosine $3^{\prime}: 5^{\prime}$-monophosphate by aspartate and glutamate in cerebral cortical slices of guinea pig. J Biol Chem 249:5955-5962.

Shimizu H, Ichishita H, Tateishi M, Umeda I (1975) Characteristics of the amino acid receptor site mediating formation of cyclic adenosine $3^{\prime}: 5^{\prime}$-monophosphate in mammalian brain. Mol Pharmacol 11 : $223-231$

Sokoloff P, Giros B, Martres MP, Bouthenet ML, Schwartz JC (1990) Molecular cloning and characterization of a novel dopamine receptor $\left(\mathrm{D}_{3}\right)$ as a target for neuroleptics. Nature 347:146-151.

Sonnenburg WK, Seger D, Beavo JA (1993) Molecular cloning of a cDNA encoding the "61-kDa" calmodulin-stimulated cyclic nucleotide phosphodiesterase. J Biol Chem 268:645-652.

Surmeier DJ, Eberwine J, Wilson CJ, Cao Y, Stefani A, Kitai T (1992) Dopamine receptor subtypes colocalize in rat striatonigral neurons. Proc Natl Acad Sci USA 89:10178-10182.

Tanabe Y, Masu M, Ishii T, Shigemoto R, Nakanishi S (1992) A family of metabotrophic glutamate receptors. Neuron 8:169-179. 
Towbin H, Staehelin T, Gordon J (1979) Electrophoretic transfer of proteins from polyacrylamide gels to nitrocellulose sheets: procedure and some applications. Proc Natl Acad Sci USA 76:4350-4354.

Wallace RW, Tallant EA, Cheung WY (1980) High levels of heatlabile calmodulin-binding protein $\left(\mathrm{CaM}-\mathrm{BP}_{80}\right)$ in bovine neostriatum. Biochemistry 19:1831-1837.

Weiner DM, Levey AI, Sunahara RK, Niznik HB, O'Dowd BF, Seeman $P$, Brann MR (1991) $D_{1}$ and $D_{2}$ dopamine receptor $m R N A$ in rat brain. Proc Natl Acad Sci USA 88:1859-1863.

Wilson ML, Higgins GA (1989) In situ hybridization. In: Neuromethods. Molecular neurobiological techniques, Vol 16 (Boulton AA, Baker GB, Campagnoni AT, eds), pp 239-284. Clifton, NJ: Humana.
Wood JG, Wallace RW, Whitaker JN, Cheung WY (1980) Immunocytochemical localization of calmodulin and a heat-labile calmodulin-binding protein $\left(\mathrm{CaM}-\mathrm{BP}_{80}\right)$ in basal ganglia of mouse brain. $\mathrm{J}$ Cell Biol 84:66-76.

Xia Z, Refsdal CD, Merchant KM, Dorsa DM, Storm DR (1991) Distribution of mRNA for the calmodulin-sensitive adenylate cyclase in rat brain: expression in areas associated with learning and memory. Neuron 6:431-443.

Young WS III, Bonner TI, Brann MR (1986) Mesencephalic dopamine neurons regulate the expression of neuropeptide mRNAs in the rat forebrain. Proc Natl Acad Sci USA 83:9827-9831. 